\title{
Mario Iazzolino, «Balzac e Les Illusions perdues»
}

\section{Marco Stupazzoni}

\section{(2) OpenEdition}

\section{Journals}

\section{Edizione digitale}

URL: https://journals.openedition.org/studifrancesi/46087

DOI: 10.4000/studifrancesi.46087

ISSN: 2427-5856

\section{Editore}

Rosenberg \& Sellier

\section{Edizione cartacea}

Data di pubblicazione: 1 octobre 2007

Paginazione: 464-465

ISSN: 0039-2944

\section{Notizia bibliografica digitale}

Marco Stupazzoni, «Mario Iazzolino, «Balzac e Les Illusions perdues»», Studi Francesi [Online], 152 (LI I

II) | 2007, online dal 30 novembre 2015, consultato il 24 novembre 2021. URL: http://

journals.openedition.org/studifrancesi/46087 ; DOI: https://doi.org/10.4000/studifrancesi.46087

Questo documento è stato generato automaticamente il 24 novembre 2021.

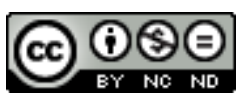

Studi Francesi è distribuita con Licenza Creative Commons Attribuzione - Non commerciale - Non opere derivate 4.0 Internazionale. 


\title{
Mario Iazzolino, «Balzac e Les Illusions perdues»
}

\author{
Marco Stupazzoni
}

\section{NOTIZIA}

MARIO IAZZOLINO, «Balzac e Les Illusions perdues», in «Quaderni dell'Accademia Cosentina», dicembre 2004, n. 40, pp. 5-37.

1 Insieme a molti altri capolavori della Comédie humaine, Illusions perdues -l'«œuvre capitale dans l'œuvre» secondo la definizione dello stesso Balzac - è il romanzo in cui lo scrittore francese ha espresso con maggiore lucidità e intensità narrativa la sua concezione circa le mutevoli e spietate dinamiche del reale, di un mondo (e di una umanità) in continua trasformazione dominato da passioni e volontà «incapaci di inscriversi nella tradizione» (p. 13). Romanzo del reale conoscibile, dunque, ma anche romanzo sociale e romanzo di formazione teso allo svelamento dei principi e dei meccanismi ideologici e filosofici che determinano la fisionomia della nuova (e ambigua) società borghese, Illusions perdues riveste altresì un valore altamente problematico. Balzac, osserva Iazzolino, «descrive una società dove è ormai abolita la frontiera tra conoscenza e prassi» poiché «pensare significa desiderare e mettere in pratica i propri desideri» (p. 37). In questo senso, quest'opera è anche un romanzo aperto che risponde «ai bisogni di un'epoca votata ai vari cambiamenti, dove tutti, individui e gruppi, accedono a nuove forme di esistenza» (p. 15). 